\title{
A NYÍREGYHÁZI LAKOSOK ÉLETMINŐSÉGE AZ EGÉSZSÉGI ÁLLAPOT TÜKRÉBEN
}

\author{
JÁVORNÉ ERdei RenÁta \\ Dr. Fábián GERGELY \\ Dr. FÜZESI ZSUZSANNA
}

\begin{abstract}
Health Quality of the Inhabitants of Nyíregyháza in the Mirror of Their Health State Improving the health of the population, by stopping or changing unfavorable trends, has been one of the significant goals of health policy for a long time. Unfortunately and in spite of this declared aim Hungary has still not made it a major prio rity to focus on questions of health at either the individual or societal level. In modern society, local communities have an increasing role to play in the formation of the quality of health and the local communities' activity and influence has become more critical. Quality of life is made up of both subjective and objective components, with some of the most important components being health, financial situation, housing and social relations. Research related to health is where quality of life investigations are primarily found and where some of the most important results have been discovered. This area which perhaps has been the most studied dimension looks at how much health status contributes to the prosperity of individuals. The primary aim of the research is the improvement of the population and through this change, subsequent improvement of the health status of the individual, and decrease of inequality. This positive change in quality of life in a person's health can be measured by two main factors - prolonged life expectancy and the increase of the number of the years added.

This study examines the health status and the quality of life of the population utilizing subjective judgments of health status. Indicators of lower mortality are found in the counties of the north-Transdanubian region, while the highest indicators are found in the regions of the north-Great Plain and northern Hungary. Prior data show that the inhabitants of Nyíregyháza consider their health status worse than the citizens of the $\mathrm{EU}$, and although the local data is close to the national data, people in Nyíregyháza still consider their health situation to be less favorable.
\end{abstract}

Keywords: subjective health status, life quality

DOI: $10.19055 / \mathrm{ams} .2013 .4 / 10 / 11$ 


\section{BEVEZETÉS}

Megállapítható, hogy - az egészségi egyenlőtlenségek növekedése ellenére - összességében két évtizede javuló tendencia figyelhető meg a magyar lakosság egészségi állapotában. Ugyanakkor azt is el kell mondanunk, hogy Magyarország még mindig meszsze elmarad szinte valamennyi egészségmutató tekintetében az Európai Unió más országaitól, melyek esetében gyorsabb javulást figyelhetünk meg az ott élők egészségi állapotának vonatkozásában. A betegségek gyakoribb előfordulása és a kimagasló halandóság miatt a magyar lakosság rosszabb minőségü és rövidebb életre számíthat nemcsak a korábbi uniós országok, hanem a velünk együtt csatlakozott Visegrádi országokhoz viszonyítva is. (Egészségjelentés - 2010)

„Az Európai Bizottság hosszú távú erőfeszítései arra irányultak/irányulnak, hogy az egyes tagországok felkészültségét növeljék, s így képesek legyenek lakosságuk egészségének egyre magasabb szintü megőrzésé\#re és fejlesztésére.

Az Egészségügyi Világszervezet négy alapstratégiát javasol megvalósítani:

- a társadalom különböző szektorainak együttmüködését annak érdekében, hogy az összes olyan tényezőt befolyásolni lehessen, amelynek bármilyen hatása lehet a lakosság egészségi állapotának romlására vagy javulására. A tényezők alatt nemcsak a géneket és a kórokozókat, hanem a többi kérdéses területet is érti, mint az oktatás, a politikai programok és a szociális háló erôssége;

- az egészséget, illetve az egészségügyi ellátórendszerek erősítését célzó programokat és beruházásokat az eredmények hangsúlyozásával;

- a családokra és a közösségekre összpontosító integrált orvosi és egészségügyi ellátást, hátterében egy rugalmasan alkalmazkodni képes, felelősségteljes kórházi hálózattal;

- az egészség fejlesztésének és a felelősség közös viselésének sikeréhez nélkülözhetetlen a lehetséges partnerek együttmüködésre sarkallása minden szinten és bármilyen felállásban, legyen az otthon, az iskola, a munkahely, a helyi közösség, a régió vagy a tagország." (OEFI, Egészségfejlesztés a színtereken)

Az Egészségügyi Világszervezet (WHO) az 1977-es, harmincadik közgyülésén rakta le a közösségi szintü egészségfejlesztési kezdeményezések világméretü elterjedésének alapjait. Az itt született határozat kimondja, hogy ,az elkövetkező évtizedekben az egyes nemzeti kormányok és az Egészségügyi Világszervezet fő társadalmi célja az kellene legyen, hogy a világ összes polgára számára a 2000-es év végére megteremtse az egészségnek egy olyan minimumát, amely lehetővé teszi számukra a társadalmi és gazdasági értelemben produktív életvitelt" (WHO, 1993). Az ekkor elindult kampány „Egészség mindenkinek 2000-re” címen vált ismertté. Ezt követte 1978-ban az Alma-atai nyilatkozat, amely kimondta, hogy az egyéni és a közösségi felvilágosítás, oktatás alapvető elemei kell, hogy legyenek az egészségügyi alapellátásnak, majd megjelent a Lalonde-jelentés, mely dokumentum - többek között - települési népegészségüggyel is foglalkozik. 1986-ban, Ottawában tartották meg az első nemzetközi egész- 
ségfejlesztési konferenciát, melynek eredményeként született meg az Ottawai egészségfejlesztési charta, melyben azonosították az egészséges élet feltételei és forrásai. (OEFI, Az egészségfejlesztés alapelvei)

Az egészségfejlesztési célok megvalósulása érdekében fontosnak tarjuk a lakosság egészségével kapcsolatos jellemzőik felmérését, mely információk egy része kérdőíves lakossági egészségfelmérések segítségével ismerhető meg. Az általunk végzett felmérés segítségével képet kaphatunk a nyíregyházi lakosok vonatkozásában az egészséget befolyásoló életmódbeli és társadalmi tényezökröl, az egészségügyi ellátások igénybevételéről.

\section{A KUTATÁS ELŐZMÉNYEI, CÉLJA ÉS MÓDSZERE}

Nyíregyháza Megyei Jogú Város Polgármesteri Hivatal Szociális Irodája és a Debreceni Egyetem Egészségügyi Kar 2008-ban indította el Nyíregyháza lakóinak életminőség vizsgálatára azt a városi kutatássorozatot, melynek célja a városlakók életminőségének folyamatos figyelemmel kísérése, a változások elemzése és bemutatása. Eddig három lekérdezés történt, 2008-ban, 2010-ben és 2012-ben.

Fő célul tủztük ki, hogy komplex vizsgálat tárgyává tegyük Nyíregyháza lakosságának egészségi állapotát, megvizsgáljuk a lakosság életminőségét többdimenziós bio-pszicho-szociális - megközelítésből. Célunk megismerni a nyíregyházi lakosok egészségi állapotát, vizsgálni egészségmagatartásukat.

$\mathrm{Az}$ eredmények birtokában célunk az életminőséget alakító tényezök leírása, egy állapotleírás elkészítése, melynek ismeretében pontosan jellemezhető Nyíregyháza helyzete, meghatározhatóvá válnak azok a pontok, amelyhez képest egy célzott egészségterv megvalósítását követően pozitív változásokat lehet elérni a lakosság egészségi állapotában.

Jelen tanulmányban az adatok részleges feldolgozottsága mellett, a kutatás és néhány elözetes eredményének a bemutatására vállalkozunk.

A kutatási program nemzetközi és hazai mintákon alapul, mely az ún. háztartáspanel módszertanát követi. Ennek lényege, hogy elsődlegesen a városi háztartásokról gyüjt információkat, másodsorban a háztartástagok meghatározott jellemzőiröl. Sajátossága, hogy azonos lakossági mintán, azonos kérdőívvel próbálja feltárni a változásokat, úgy, hogy a kérdezők ugyanazokat a háztartásokat keresik fel meghatározott időközönként.

A háztartáspanel vizsgálatnak kialakult módszertana van az Európai Unióban és Magyarországon is. Előzménynek és részben mintának is tekinthető az ECHP kutatás (European Community Household Panel - Európai Közösség Háztartáspanel), amely standardizált kérdőívvel, azonos mintán (összességében 60.500 európai háztartásban, közel 130.000 fő esetében) vizsgálta 1994 és 2001 között az európai polgárok életkörülményeit, olyan standardizált, azaz nemzetközi viszonylatban is összehasonlítható dimenziókban, mint pl. a jövedelmi helyzet, szegénység, gazdasági aktivitás, egészségi állapot. Az uniós tagországok közül Ausztria 1995-ben, Finnország 1996-ban, míg Svédország 1997-ben csatlakozott a vizsgálathoz. Magyarország később az ECHP 
folytatásának tekinthető vizsgálatsorozatba lépett be. A kutatássorozat módosítására azért volt szükség, mert az eredetileg a mintába kerültek az idők folyamán ,eltüntek” a kutatók elöl. A nyolc éves követési idő alatt az ECHP kutatásban ugyanis olyan nagy mértékűvé vált az ún. „panelkopás” (a megkérdezésre kiválasztottak „eltünése” - költözés, elhalálozás, egyéb mobilitási problémák miatt), hogy a felvétel az eredeti elképzelésekkel ellentétben 2001-ben gyakorlatilag megszünt. Hasonló adatfelvételre ugyanakkor szükség van, különösen azért, hogy a csatlakozó országokból is rendelkezésre álljanak nemzetközileg is összehasonlítható adatok. Az ECHP folytatása az EUSILC (Statistics on Income and Living Conditions - Jövedelem és életminőség statisztika) bevezetéséröl 2000-ben határoztak az uniós tagállamok társadalomstatisztikai elnökei, az Európai Parlament pedig 2003 márciusában hagyta jóvá azt a keretszabályozási törvénytervezetet, amely elindította a kutatássorozatot. (Fábián 2009.)

Az EU-SILC alapvetően kétféle adatot eredményez:

- keresztmetszeti (időszakra vagy meghatározott időpontra vonatkozó), valamint

- longitudinális adatokat, melyek az egyének szintjén négyéves időtartamon keresztül mérik a változásokat.

A nyíregyházi vizsgálat hazai elózménye a TÁRKI által, a kilencvenes évek elején elindított Magyar Háztartás Panel (MHP - később Háztartás Monitor) országos kutatás, amely lényegében azonos módszertannal készült, mint a nemzetközi vizsgálatok, s kétéves időközönként kíséri figyelemmel a magyar háztartások életkörülményeinek alakulását, változását.

A nyíregyházi háztartáspanel vizsgálat a nemzetközi és hazai előzményeket figyelembe véve, azokra alapozva készült el, nemcsak módszertanát tekintve, hanem felhasználva az ECHP, az EU-SILC és az MHP kérdőíveit, annak érdekében, hogy a lokálisan kapott információk mind hazai, mind nemzetközi szinten összehasonlíthatóak legyenek. (Fábián 2009.)

\section{Az adatfelvétel módszere}

A vizsgálat során interdiszciplináris (egészségtudomány, szociológia, pszichológia) megközelítésben az elméleti kutatást empirikus - kérdőíves kutatással ötvöztük. A kérdőív, melyet 2012-ben a kutatói csoport több témakör vonatkozásában módosított, illetve kiegészített, több nagy blokkban igyekszik feltárni Nyíregyháza lakosságának életkörülményeit. A mi szükebb kutatócsoportunk az egészségi állapot témakörét vizsgálja.

Az adatgyüjtés az alábbi témakörökre terjed ki:

1. A háztartások jellemzői (háztartás összetétele, lakhatás körülményei, problémák, háztartások felszereltsége, jövedelmek)

2. Gazdasági aktivitás (munkavégzéssel kapcsolatos jellemzők)

3. Egészségi állapot (egészségi állapot megítélése, tartós betegségek)

4. Társas kapcsolatok (családi és emberi kapcsolatok jellemzői, kiterjedtsége, intenzitása)

5. Idősek helyzete (a 65 éves, illetve annál idősebb lakosok helyzete) 
6. Támogató rendszerek - szociális problémák (a természetes és mesterséges védőháló jellemzői, segélyezés, vélemények a segélyezési rendszerekről, szociális ellátásról)

7. Szociális Iroda müködése (ügyfelek és véleményük)

8. Biográfia (a megkérdezettek személyes jellemzői)

A kérdőíves felmérés során az adatgyüjtés kérdezőbiztosok segítségével történik, akik a Debreceni Egyetem Egészségügyi Kar hallgatói közül kerülnek ki. A kérdezőbiztosok előzetes felkészítésben részesülnek, a megkérdezettek, pedig egy részletes tájékoztató levelet kapnak a Polgármesteri Hivataltól az alpolgármester és a kutatás vezetőjének aláirásával, arról, hogy milyen cél érdekében és mikor keresik fel öket a kérdezöbiztosok.

2012-ben a kérdőívet a kutatók kisebb-nagyobb módosításokkal, kiegészítéssel látták el. Az előző két lekérdezés során használt vélt egészségi állapotot mérő kérdéssort kiegészítettük az ELEF 2009. címü kutatás néhány kérdésével, mely lehetővé teszi számunkra a minél korrektebb összehasonlítást.

A mintaválasztást a Magyar Háztartás Panel módszertanára alapoztuk. A megkérdezettek közé azok kerültek be, akik 18. életévüket betöltötték és a város állandó lakói. A minta kiválasztását az említett kitételek alapján a Közigazgatási és Elektronikus Közszolgáltatások Központi Hivatala végezte véletlenszerủen az adatbázisából, úgy, hogy kialakításra került egy 2000 fös föminta és egy 400 fős pótminta, arra az esetre, ha nem vállalják a válaszadást, vagy valamilyen okból kiesnek a fömintából.

Mivel a városlakókról a népszámlálási adatokból rendelkezésünkre állnak adatok, a mintával kapcsolatos információink pedig kizárólag a névre és címre korlátozódtak, ezért a kiválasztott minta reprezentativitása a nemek megoszlása alapján került tesztelésre, ami viszonylag állandónak is mondható.

Célul tüztük ki, hogy a határon túli, magyar lakosság körében is elvégezzük a kutatást, így lehetőség nyílik a nemzetközi, európai összehasonlítások mellett, egy az EU keleti régiójára jellemző összevetést végezni. A megvalósítás érdekében felvettük a kapcsolatot a Nagyváradi Partiumi Keresztény Egyetemmel, a Kolozsvári Babes-Bolyai Egyetemmel és az Ungvári Nemzeti Egyetemmel. Jelen időszakig a kolozsvári egyetemhez kötődő tudományos diákköri tevékenységet folytató hallgatóknak sikerült a lekérdezést megvalósítani Gyergyószentmiklóson, mely vizsgálat eredményeiből két tanulmány is születetett.

Az adatok feldolgozása és elemzése az SPSS for Windows statisztikai szoftvercsomag alkalmazásával történik. Az elemzés során általunk relevánsnak tartott változók gyakorisági értékeit elemezzük, melyeket egy- és kétváltozós matematikai-statisztikai módszerekkel számítunk ki (átlag, szórás, gyakorisági eloszlás, valamint kétmintás t-próba, függetlenség-teszt (khi négyzet-próba). Az adatok feldolgozása és elemzése még nem zárult le, jelenleg előzetes adatokat áll módunkban közölni tanulmányainkban. 


\section{EREDMÉNYEK}

Az eredmények bemutatása előtt fontosnak tarjuk a szubjektív, vélt egészségi állapot fogalmának tisztázását és jelentőségének alátámasztását.

A kutatásokat végző személyek számára nem minden esetben mérhető fel maradéktalanul a megkérdezettek egészségi státusza, ezért jobb eredmények érhetők el abban az esetben, ha maguk a megkérdezettek mutatják be, illetve minősítik azt (Ware 1986). A válaszadók képesek átlátni, megérteni saját egészségi állapotukat, ők ismerik egészségüket, ezért ez az eljárás alkalmas arra, hogy az egészségi állapotot holisztikus szempontból közelítse meg és mérje. Bár ez egy szubjektív tartalmú kategória, reliabilitása alátámasztott, továbbá prediktív funkciója pontosabb, mint az objektív mérésé (Tahin - Jeges - Lampek 2000). „Az ún. önminősített egészségi állapot egyfajta szubjektív értékelés, azonban az objektív fizikai státusszal is szorosan összefügg, ezért alkalmas a betegségfolyamatok monitorozására."- írja Pikó Bettina (Pikó 2006).

A népegészségügyi kutatásokban is gyakran találkozhatunk azzal az egészségszemlélettel, amely a percepcionális modellt követi, amikor is az egészség meghatározása az egyén saját véleménye alapján történik. A szubjektív, vélt egészséget több nemzetközi szervezet is - mint például az OECD, WHO - ajánlja egészségindikátorként.

Az Európai Lakossági Egészségfelmérésben a következőképpen definiálták a vélt egészségi állapot: „A vélt egészség az egyének önértékelésén alapul, vagyis azon, hogy milyen a véleményük a saját egészségi állapotukról. Nem függ össze szorosan a tényleges, orvosilag igazolt diagnózissal, megítélését befolyásolja az egyén társadalmi, gazdasági, kulturális helyzete, mégis a nemzetközi gyakorlatban a kérdés elfogadott és rendszeresen alkalmazott eszköze a lakosság egészségi állapotára vonatkozó vizsgálatoknak."(ELEF kérdőív)

A jelenlegi és a kötetben szereplő további egészségi állapot és életminőség problémakört elemző tanulmány, tanulmányok a 2012-es nyíregyházi háztartáspanel vizsgálat szubjektív egészségi állapotra vonatkozó előzetes eredményeinek egy részét mutatja be.

Az ELEF 2009-es eredményeiböl ismert, hogy a magyar felnőtt lakosság nagy része elégedett egészségi állapotával, vagy legalábbis megfelelőnek tartja azt. A nők és férfiak, több, mint fele jónak vagy nagyon jónak ítéli meg egészségi állapotát. A férfiak közel $12 \%$-a és a nők $17 \%$-a véli rossznak, vagy nagyon rossznak egészségét. Az európai társadalmak közel kétharmada tartja jónak egészségi állapotát, amit ha összevetünk a magyarországi adatokkal, lemaradást tapasztalunk a magyar lakosok vélt egészségi állapotában.

Ha az 1. ábrát megvizsgáljuk, láthatjuk a város lakóinak égészség érzetét. Megállapítható, hogy mind a magyar, mind az európai lakosokhoz képest a nyíregyházi lakosság kedvezőtlenebbnek értékeli egészségét. Ugyanakkor észre kell vennünk, hogy a 2008-ban és 2010-ben mért adatokhoz képest csökkent azok aránya, akik rossznak, vagy nagyon rossznak ítélik meg egészségi állapotukat. A csökkenéssel körülbelül egyező mértékben nőtt az egészségüket elfogadhatónak, vagy nagyon jónak megítélők aránya. Az egészségi állapotukat jónak megítélők aránya az utóbbi két adatfelvétel során nem változott. Ezek az eredmények tendenciaszerü változást mutatnak. 
1. ábra Az egészségügyi állapot szubjektív jellemzése Nyíregyházán (2008-2010-2012) (\%)

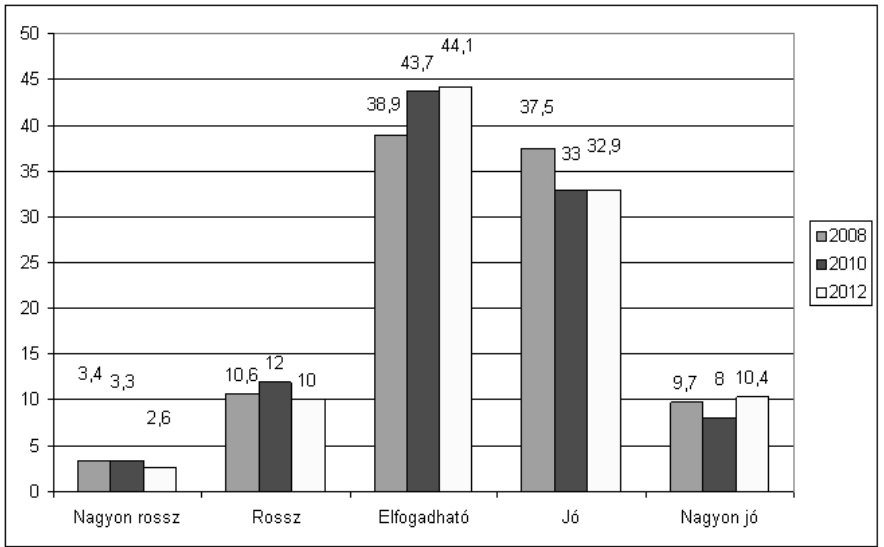

Ismert az a tény, hogy a nők morbiditása rosszabb, mortalitása viszont jobb a férfiakénál. Ez azzal magyarázható, többek között, hogy a nők érzékenyebbek egészségi állapotuk változására és ezért korábban fordulnak orvoshoz, mint a férfiak, továbbá, hogy azok a betegségek, amelyek körükben előfordulnak, általában sikeresebben kezelhetők. A 2. ábrán látható, hogy Nyíregyházán a férfiak és nők körében mért adatok kedvezötlenebbül alakulnak a magyar lakosságéhoz képest, az ELEF 2009 adatai azt mutatják, hogy a nők körében eléri, férfiak esetében pedig meghaladja az 50\%-ot azok aránya, akik egészségi állapotukat jónak tartják. Az előző, 2010-es adatfelvételhez viszonyítva 2012-ben a férfiak körében némiképp romlott, a nők esetében pedig javult az önminősített egészségi állapot, a nők körében emelkedett azok aránya, akik jónak ítélik meg egészségi állapotukat, bár ez az országos adatokhoz képest még mindig alacsonyabb arányú.

A nőknek a férfiakénál sokkal kedvezőbb életesélyei, illetve ebben a vonatkozásban a két nem között növekvő különbség talán annak köszönhető, hogy a nők egészségtudatosabban élnek, életmódjukban kevesebb az egészségkárosító tényező, mint a férfiakéban, gondoljunk például a dohányzásra, az alkoholizmusra és a táplálkozási szokásokra. Szeretnénk hangsúlyozni azt a feltételezésünket - melyet a további vizsgálatok során tisztázunk - miszerint a nemek közötti különbségek társadalmi státusz szerint differenciáltan jelennek meg, azaz, az egyenlőtlenségek az egészségmagatartásban is regisztrálhatóak.

Az iskolai végzettség és a szubjektív egészségi állapot közötti összefüggés vizsgálata során esetünkben is jól látható, hogy az alacsonyabb iskolai végzettségü csoportokban az egészségi állapot önértékelése negatívabb (3. ábra). Azt is megállapíthatjuk, hogy az is- 
kolai végzettség emelkedésével nő azok aránya, akik egészségi állapotukat elfogadhatónak, jónak ítélik meg, azaz a magasabb iskolai végzettséghez általánosságban jobb egészségi állapot társul.

2. ábra A vélt egészség nemenként (\%)

Nyíregyháza és ELEF - 2008 - 2010 - 2012

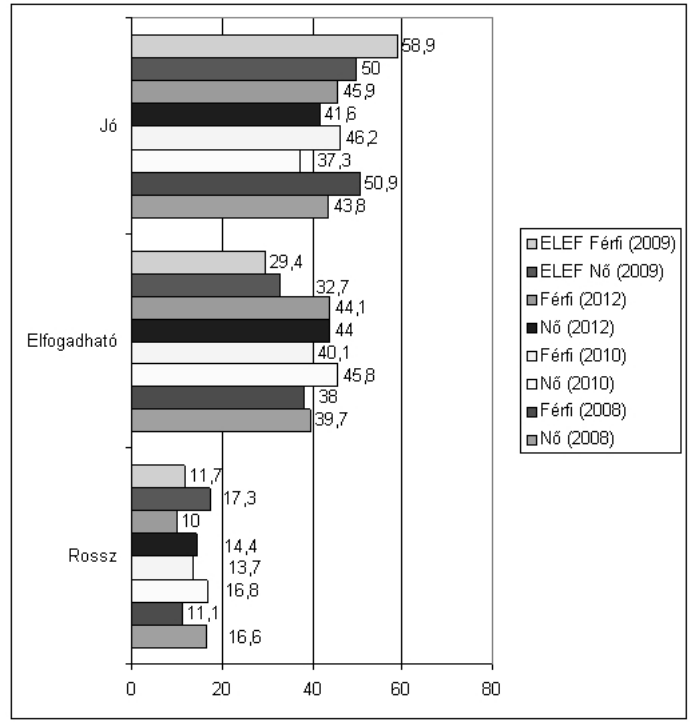

A lakosság egészséget befolyásoló életmódbeli és társadalmi tényezőinek vizsgálatán túl, - melyből e tanulmányban csupán néhány dimenzió bemutatására van mód - igyekeztünk feltárni, hogy a válaszadók milyen gyakorisággal találkoznak orvosukkal. Az egészséget befolyásoló tényezők közül az egyének lehetőségeinek, felelösségének megítélésében a magyar lakosok többsége egyetért abban, hogy a biológiai adottságokon kívül az egyén hozzáállásán, az egészség érdekében tett erőfeszítéseiken is múlik egészségük. Az egyén felelőssége abban is tetten érhető, hogy mikor, milyen panaszok esetén és milyen gyakorisággal fordul háziorvosához. Fontosnak tartja-e, hogy egészségi állapotának ellenőrzése céljából, például szűrővizsgálatok elvégzése miatt felkeresse orvosát, vagy csupán panaszok esetén megy el háziorvosához. A magyar lakosság 76\%-a rendszeresen, évente legalább egyszer keresi fel háziorvosát, 39\%-uk egyszerkétszer, a többiek ettől gyakrabban látogatják meg orvosukat (ELEF 2009). 
3. ábra Az egészségi állapot szubjektív jellemzése Nyíregyházán $2008-2010-2012(\%)$

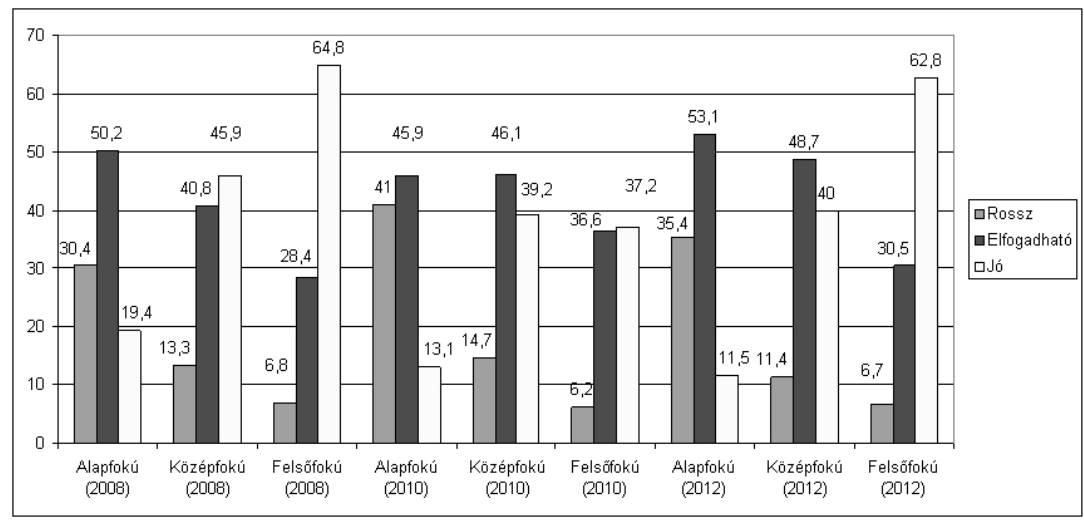

A 4. ábra a nyíregyházi lakosok háziorvosi ellátásának igénybevételét, valamint annak motivációs hátterét mutatja. Az adatokból az olvasható ki, hogy a város lakói döntően panasz esetén, akkor is csak nagyobb panasz, nagy fájdalom, vagy kényszer hatására mennek el háziorvosukhoz, amíg lehet, halogatják az orvosi vizsgálatot. Ezen jellemzők háttértényezőinek vizsgálata még tart, nagyon lényeges ebben az esetben is feltárni azt, hogy leírhatók-e jellemzők a társadalmi-gazdasági helyzet, az egyes körzetek stb. mentén. Ezeket az összefüggés elemzéseket egy későbbi tanulmányban tesszük közzé.

4. ábra Háziorvosi ellátás igénybevétele a Nyíregyházi lakosok körében 2012 (\%)

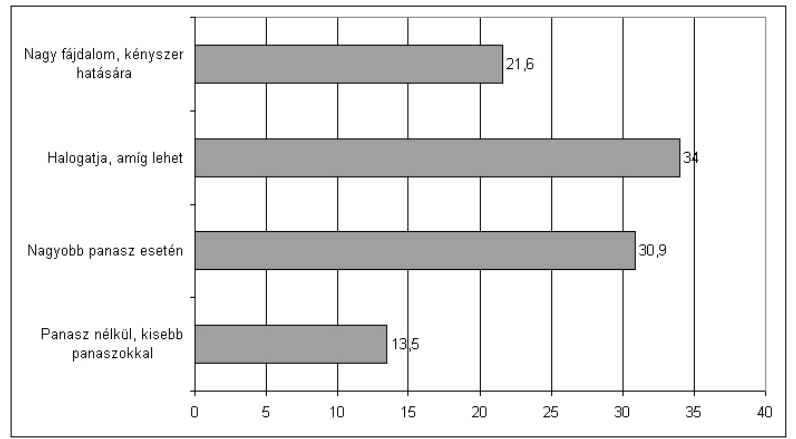




\section{ÖsSZEFOGLALÁs}

A 2012. évi vizsgálat előzetes eredményei azt mutatják, hogy a 2010-es felméréshez képest a nyíregyházi lakosok egészségérzete minimálisan javult. Továbbra is jellemző városunkban is az, hogy a nők kedvezőtlenebbnek ítélik meg egészségi állapotukat, mint a férfiak. Az egészségi állapottal legszorosabb összefüggést az iskolai végzettség mutatja, azaz minél alacsonyabb iskolai végzettséggel rendelkezik valaki, annál kedvezőtlenebbül ítéli meg egészségi állapotát. Sajnálatos az, hogy a lakosság nagy része csak nagyobb panaszok esetén fordul háziorvosához, nem veszi igénybe a lakossághoz legközelebb álló egészségügyi alapellátás preventív és gyógyító lehetőségeit.

A jövőben, a részletes elemzésekben az adatok többváltozós vizsgálatával leírhatóvá válik a társadalmi-gazdasági háttér változóinak szerepe, továbbá az egyes tényezők számszerüsíthető hatása.

Az eredmények birtokában lehetővé válik a nyíregyházi lakosok életminőségét alakító tényezők leírása, egy állapotleírás elkészítése, melynek birtokában pontosan jellemezhető Nyíregyháza lakosságának helyzete, továbbá meghatározhatóvá válik az a pont, amelyhez képest egy célzott egészségterv megvalósítását követően pozitív változásokat lehet elérni a lakosság egészségi állapotában.

\section{FelHasznált irodalom}

1. Ádány Róza (2009): A magyar lakosság egészségi állapota, különös tekintettel az ezredforduló utáni időszakra. Népegészségügy 86. évf. 2. szám 5-20. oldal.

2. Az egészségfejlesztés alapelvei (2004): (Az egészségfejlesztés alapvető nemzetközi dokumentumai) - Országos Egészségfejlesztési Intézet.

3. Egészségfejlesztés a színtereken (2004): Országos Egészségfejlesztési Intézet

4. Egészségfelmérés (ELEF), 2009 (2010) Statisztikai tükör, IV. évfolyam 50. szám.

5. Fábián Gergely (2009) Életminőség Nyíregyházán. Jövedelmi helyzet, egyenlötlenségek és egészségi állapot. Szabolcs-Szatmár-Bereg megyei szemle 4. szám 569-589. oldal.

6. Fábián Gergely - Patyán László - Huszti Éva (2012): Életminőség Nyíregyházán 2008-2010. DE-OEC Nyíregyháza.

7. Dr. Füzesi Zsuzsa - Dr. Tistyán László (2004): Egészségfejlesztés és közösségfejlesztés a színtereken. OEFI.

8. Füzesi Zs. (2004): Egészségmagatartás - Népegészségügyi jelentés, szakértői változat Bp., Országos Epidemiológiai központ, 5. fejezet pp. 1-86.

9. Jelentés egy egészségben elmaradott országból... Egészségjelentés - 2010 (2010): Egészségmonitor Kutató és Tanácsadó Nonprofit Közhasznú Kft., Budapest.

10. Kopp Mária - Kovács Mónika (2006): A magyar népesség életminősége az ezredfordulón, Semmelweis Kiadó, Budapest.

11. Mogyorósy Zsolt, Szende Ágota, Mogyorósy Gábor, Böszörményi-Nagy Klára - A gyógyító - megelőző eljárások értékelésénél használt szakkifejezések szótára. 
12. Novák Márta - Stauder Adrienne - Mucsi István (2003): Az életminőség vizsgála tának jelentősége és gyakorlati szempontjai, Orvosi Hetilap.

13. Népegészségügyi Jelentés (2011): Országos Epidemiológiai Intézet.

14. Pikó Bettina (2002): Egészségszociológia, Új Mandátum Könyvkiadó Budapest.

15. Pikó Bettina (2006): Orvosi szociológia, Medicina Kiadó, Budapest.

16. Tahin Tamás - Jeges Sára - Lampek Kinga (2000) Iskolai végzettség és egészségi állapot, Demográfia 1.

17. Tistyán L., Busa Cs., Füzesi Zs.(2012): A mentális betegségek, panaszok és az egészségmagatartás összefüggései - Európai lakossági egészségfelmérés. Tanulmányok II.-Az egészség társadalmi gazdasági összefüggései: $\mathrm{KSH}, \mathrm{pp} .32-52$.

18. Tokaji Károlyné (2011): Objektíven szubjektív, Statisztikai szemle, 89. évfolyam 7-8 szám.

19. Vitrai József, Vokó Zoltán (2004): NEJ-2004 Egészségmodell, Szakértői változat.

20. Ware, J.E. (1986): The assessment of health status. In.: Aiken, L.H. - Mechanic, D. (eds.): Application of social science of clinical medicine and health policy Rutgers University Press, New Jersey 204-208. 
